\section{Indian and Other Projects}

In Rajasthan, India, a similar project was started in 1984 which is following the peoples' struggle against the advancing desert. Two films made by an Indian crew based in New Delhi have been transmitted in India and distributed internationally by TVE and CENTRAL. TVE is now planning to develop a similar project in Zimbabwe.

Other projects involving North-South co-productions are planned. TVE is also giving small grants to help independent film producers to get films under way in China, Oman, and the Himalaya. Its most recent co-productions were with the $\mathrm{BBC}$ on whaling and soil erosion. A European co-production on acid rain involving CENTRAL, and TV stations in Austria, the Netherlands, and Sweden, was broadcast late in 1986.

Although TVE will continue to work in the background, helping to get new productions under way, it is giving priority to developing an international Clearinghouse sys- tem designed to promote the showing of more films on environmental issues. Its main aim will be to provide assistance to producers and broadcast outlets in 'developing' nations. TVE has already published a critical guide to some of the best films on environment and development. Nearly 1,000 films were viewed, out of which 100 were selected for the catalogue.

As part of the Clearinghouse project, TVE is also participating in a newly-launched scheme to provide students in developing countries with printed and audiovisual materials on environment and health. Support for this project has so far come from UNEP, WWF, UNICEF, and the New York Zoological Society.

Robert P. LAMB, Director

TVE Television Trust for the Environment 46 Charlotte Street

London WIP $1 L X$

England, UK.

\title{
Environmental Successes Honoured by UNEP: The Global 500
}

The United Nations Environment Programme has announced 90 awards in 43 countries for 'outstanding environmental achievements'-an initiative which has apparently been successful, attracting considerable media and political attention. Those honoured by UNEP ranged from an American actor. Robert Redford, to villagers in Africa, Asia, and Latin America. Redford received his UNEP award for supporting due protection of vulnerable areas by sound environmental management-an aim pursued by the Institute for Resource Management, which he founded.

UNEP Executive Director Dr Mostafa K. Tolba describes the awards, which recognize work in protecting and improving the environment, as 'tributes to success on the front lines of the global cause of the environment'. UNEP calls its awards list the 'Global 500', because it intends to select and recognize 500 such achievements over the five years to 1991. For this first batch of such awards, UNEP received more than 450 nominations of environmental activists, whether individuals or organizations, from 70 countries for the 1987 awards, and is already receiving nominations for 1988 .

The list of awards for 1987 was announced on the eve of World Environment Day, June 5, at UNEP's world headquarters in Nairobi, Kenya, and at national ceremonies elsewhere. (UNEP has published a 'Who's Who' booklet with brief descriptions of the work of the award winners, which is available on request from the undersigned.)

The first batch of 'Global 500' laureates include villagers protecting vulnerable farmlands and forests in remote areas of Africa, Asia, and Latin America, as well as prominent figures in science, diplomacy, politics, and the media, who are active in environmental causes.

Dr Tolba, the Egyptian microbiologist who has headed UNEP since 1976, presented the award certificates to a score of recipients who were able to be present in Nairobi. He told the large international audience at the ceremony: 'Their work for the environment deserves the thanks of the world. We hope their example will encourage others to preserve and enhance the environment which is the lifesupport system of our planet'.

The activities of the award-winners include forestry, marine research, wildlife protection, antipollution campaigns, energy-saving, urban renewal, soil and water conservation, film-making, legislation, and information.

There were 18 awards in Africa, 13 in Latin America, 17 in the Asia-Pacific Region, 3 in the Arab World, one in Israel, 13 in Western Europe, 6 in Eastern Europe, 3 in Canada, and 16 in the US.
Among the recipients of the UNEP awards on this occasion were:

- M. Bernard Ouedraogo, of Burkina Faso, Africa, leader of forest and water conservation projects in 700 villages in the Sahel.

- Miss Ulli Sigar, a popular Indonesian singer who uses music to take the message of environmental protection to villages in many parts of Java.

- Señor Carlos Pizani, field director of the Rapa Nui National Park on Easter Island in the Pacific Ocean.

- The National Geographic Society, USA, whose publications have, since 1890, reported in words and photographs on the world's natural heritage and cultures. At the awards ceremony in Nairobi, the Society presented a memorable audiovisual 'portrait of the beauty and diversity of the world.'

- Mrs Marion Stoddart, of Boston, USA, who successfully compaigned for cleansing of the polluted Nashua River in Massachusetts, USA.

- Mrs Lily Venizelos, of Greece, leader of campaigns to protect the Mediterranean breeding-grounds of marine turtles.

- Mr Sekkou Zouha, the leader of desert control projects in the Draa Valley, Morocco.

- Mr Ben Soans, whose village teams have planted millions of trees in southern India.

- Mrs Sophie Kiarie, of Kenya, who promotes village use of cookstoves designed to use less wood and thus save trees.

- Sir Edmund Hillary, the Himalayan climber who is now New Zealand Ambassador to Nepal, where he helped to found the national park near Mt Everest.

- Dr Grigory Galazii, a Soviet scientist who has long worked to prevent and reverse industrial pollution of Lake Baikal in Siberia.

- Mr Thomas Landgren, leader of a community group in Gallspang, Sweden, which is active in Nature conservation and control of waste disposal.

- The Green Great Wall Group, an organization of villagers planting millions of trees along the Great Wall of China, to conserve soil and moderate climate.

- The Arab Office of Youth and Environment, Cairo, the leading environmental action group in the Arabic-speaking world.

JoHN SHaw, Information Officer UNEP

P.O. Box 30552

Nairobi

Kenya. 